\title{
Implementasi pemasaran digital berbasis website sebagai strategi kenormalan baru Dusun Srumbung Gunung pasca Covid-19
}

\author{
Evi Maria ${ }^{(\mathbb{D})}$, Suharyadi, \& Rini Kartika Hudiono \\ Universitas Kristen Satya Wacana, Indonesia \\ *evi.maria@uksw.edu
}

\begin{abstract}
Covid-19 has an impact on the decrease in trading activity in Dusun.Srumbung Gunung, because marketing activities still rely on physical stores. The purpose of community service activities is to develop a Pasar Dusun website and train website administrators welcoming the new normality. This activity was carried out with a descriptive approach using two methods. First, mentoring was done to start the Website of Pasar Dusun. Second, the training of administrators who are in charge and responsible for managing trade transactions that occur on the website of Pasar Dusun was carried on. The result of this activity is the availability of a Dusun Market website that can be accessed on https://pasardusun.sakoo.id/. Since, August 13, 2020 to September 19, there have been 9 successful trade transactions on the website of Pasar Dusun with a total of 165 products sold. This shows the contribution of digital marketing to increase the income of villagers after Covid-19. The results of the training of administrators, website managers have been able to maintain and update information related to buying and selling activities on the website of Pasar Dusun.
\end{abstract}

Absrak Covid-19 membawa dampak pada penurunan aktivitas perdagangan di Dusun.Srumbung Gunung, karena kegiatan pemasaran masih mengandalkan toko fisik. Tujuan kegiatan pengabdian kepada masyarakat adalah membangun website Pasar Dusun dan melatih administrator website menyambut kenormalan baru. Kegiatan ini dilakukan dengan pendekatan deskriptif dengan dua metode. Pertama, pendampingan untuk membuka website Pasar Dusun. Kedua, pelatihan administrator yang bertugas dan bertanggungjawab untuk mengelola transaksi jual beli yang terjadi dalam website Pasar Dusun. Hasil kegiatan ini adalah tersedianya website Pasar Dusun yang dapat diakses di https://pasardusun.sakoo.id/. Sejak tanggal 13 Agustus 2020 sampai tanggal 19 September sudah adanya 9 transaksi jual beli yang berhasil di website Pasar Dusun dengan total 165 produk yang laku terjual. Ini menunjukkan kontribusi pemasaran digital untuk meningkatkan pendapatan warga desa pasca Covid-19. Hasil pelatihan administrator, pengelola website sudah dapat melakukan pemeliharaan dan pembaharuan informasi terkait aktivitas jual beli di website Pasar Dusun.

Keywords: digital marketing; website; Srumbung Gunung; new normality; Covid-19

\section{OOPEN ACCESS}

Citation: Maria, E., Suharyadi., \& R. K. Hudiono. (2021). Implementasi pemasaran digital berbasis website sebagai strategi kenormalan baru Dusun Srumbung Gunung pasca Covid-19. Riau Journal of Empowerment, 4(1), 1-10. https://doi.org/10.31258/raje.4.1.1-10

Received: 2021-03-16 Revised: 2021-04-13 Accepted: 2021-04-20

Language: Bahasa Indonesia (id)

Funding: Kementrian Riset Teknologi / Badan Riset Inovasi Nasional Republik Indonesia

ISSN 2623-1549 (online), 2654-4520 (print)

(c) 2021 Evi Maria, Suharyadi, \& Rini Kartika Hudiono. Author(s) retain the copyright of article published in this journal, with first publication rights granted to Riau Journal of Empowerment. The article is licenced under Creative Commons Attribution 4.0 International License. This license permits unrestricted use, distribution, and reproduction in any medium, provided the original author and source are credited. 


\section{PENDAHULUAN}

Pandemi Covid-19 yang melanda dunia, tak terkecuali di Indonesia belum menunjukkan tanda-tanda akan berakhir. Para ahli masih bekerja keras untuk mengembangkan vaksin dan obat untuk mengendalikan virus tersebut. Tak heran jika sampai sekarang, siapa pun akan sulit memprediksi kapan pandemi akan berakhir. Pemberlakuan Peraturan Pemeritah No. 21/2020 tentang Pembatasan Sosial Berskala Besar Dalam Rangka Percepatan Penanganan Corona Virus Disease 2019 (COVID-19) di berbagai wilayah di Indonesia, tentunya membawa konsekuensi pada lesunya aktivitas ekonomi dan perdagangan di Indonesia. Meskipun lambat, perekonomian Indonesia triwulan I 2020 masih tumbuh sebesar 2,97 persen year-on-year (yoy). Namun tidak di triwulan II 2020, pertumbuhan ekonomi Indonesia mengalami kontraksi sebesar -5,32 persen (Badan Pusat Statistik, 2020). Covid-19 telah membuat perekonomian Indonesia berada pada zona krisis. Kondisi ini tentunya membuat khawatir banyak pihak.

Karakteristik krisis ekonomi yang disebabkan oleh Covid-19 ini, tentunya sangat berbeda dengan karakteristik krisis yang terjadi di Indonesia tahun 1997-1998 dan 2008-2009 dulu. Fakta, virus corona yang mematikan dan penyebaran virus yang relatif cepat membuat pemerintah harus membuat kebijakan cepat dan tepat untuk mencegah penyebaran virus lebih luas, seperti physical distancing dan pembatasan sosial berskala besar baik skala nasional maupun internasional (Fernandez \& Shaw, 2020). Kebijakan ini mengantam seluruh aktivitas perdagangan baik di kota, desa, dan antar pulau di seluruh pelosok negeri ini. Tak hanya pedagang besar, Usaha Mikro Kecil dan Menengah (UMKM) bahkan petani pun mengalami penurunan penjualan dan pendapatan akibat Covid-19. Ini karena sebagian besar aktivitas perdagangan yang dilakukan oleh pelaku bisnis di Indonesia masih mengandalkan toko fisik dan penjualan langsung (Maria, 2020). Covid-19 membuat UMKM tidak lagi dapat diandalkan untuk menopang pertumbuhan ekonomi Indonesia.

Dusun Srumbung Gunung, Desa Poncoruso, Kabupaten Semarang merupakan salah satu desa yang aktivitas perdagangannya terdampak Covid-19. Warga dusun ini banyak yang bermata pencaharian sebagai petani sayuran dan hortikultura karena dusun ini memiliki tanah yang cocok untuk pertanian. Petani di dusun tersebut menghadapi kesulitan distribusi hasil panen karena putus kontrak dengan pengusaha rumah makan dan hotel yang usahanya tutup sementara saat pandemi berlangsung (Maria, 2020). Tak hanya itu, Covid-19 juga mengurangi jumlah kedatangan penjual dan pembeli di pasar tradisional tempat para petani dan pedagang memasarkan dagangannya. Akibatnya, terjadi penurunan pendapatan dan kesejahteraan warga dusun. Tak sedikit juga, para petani dan pedagang di dusun tersebut yang mengalami kerugian karena tidak dapat menjual barang dagangannya. Selain itu, beberapa UMKM di sana juga terpaksa harus mengurangi karyawannya dengan melakukan Pemutusan Hubungan Kerja (PHK) agar dapat mempertahankan usahanya ditengah pandemi. Pariwisata desa pun tidak berjalan, tingkat kedatangan wisatawan pun menurun drastis karena pandemi ini. Ekonomi pedesaan dengan tingkat wirausaha yang tinggi dan UMKM dengan solvabilitas dan cadangan kas yang terbatas, tentunya kurang siap menghadapi gangguan yang disebabkan oleh Covid19. Kondisi ini tentunya tidak dapat dibiarkan begitu saja. Desa memerlukan strategi untuk memasuki kondisi kenormalan baru pasca Covid-19. Salah satu strategi kenormalan baru desa yang diinisiasi oleh Kementerian Desa, Pembangunan Daerah Tertinggal dan Transmigrasi Republik Indonesia adalah dengan membangun digitalisasi ekonomi desa, melalui implementasi pemasaran digital (Firman, 2020).

Digitalisasi ekonomi desa diyakini menjadi solusi pemulihan ekonomi desa pasca Covid19. Kenormalan baru desa menuntut perubahan model ekonomi dari bentuk konvensional ke 
digital dengan memanfaatkan teknologi informasi dan komunikasi (TIK). Pemanfaatan TIK diyakini membuka peluang bagi masyarakat desa untuk memasarkan produk dan potensi yang dimiliki desa dalam jangkauan yang lebih luas. Bagi para petani di desa, pemanfaatan TIK dalam pemasaran diyakini dapat memperpendek rantai distribusi hasil pertanian dan dapat memutus rantai tengkulak yang selama ini membuat harga hasil pertanian tidak wajar diserap pasar. Pedagang di desa tak hanya mendapat akses jangkauan pemasaran yang luas, tetapi juga dapat memperoleh pemasok barang dagangan dengan harga yang lebih murah di pasar online. Riset Utomo, Retnowati and Maria (2014); Kurnia et al. (2015); Utomo, Retnowati and Maria (2015); Maya (2016); Awiagah, Kang and Lim (2016) mengkonfirmasi bahwa penggunaan TIK dalam bentuk e-commerce oleh UMKM bermanfaat untuk memperluas jangkauan pemasaran dan komunikasi bisnis antara rekan bisnis, pemasok, dan pelanggan, sehingga berdampak pada peningkatan pendapatan.

Aplikasi TIK, seperti sistem pertanian digital yang diimplementasikan di perdesaan diidentifikasi dapat membawa perubahan dalam sosial ekonomi masyarakat desa (Hoffman, Novak and Chatterjee, 1995; Shen, Basis and Howard, 2010; Patel and Sayyed 2014). Masyarakat perdesaan bergantung pada pertanian dan hutan sebagai mata pencahariannya, sehingga tidak sedikit dari petani harus berurusan dengan kegagalan panen karena pengaruh dari iklim, hama penyakit, dan lainnya. Oleh sebab itu, sistem pertanian digital diimplementasikan untuk membuat basis data terkait pertanian mulai dari kondisi tanah, iklim, benih unggul, hingga pasar (Shen, Basis and Howard 2010). Data-data tersebut digunakan untuk membantu membuat keputusan yang lebih baik, mulai dari proses produksi, pemasaran produk pertanian sampai mengembangkan rencana perlindungan bagi produsen dan menghasilkan rencana pengelolaan mutu tanah. Penggunaan TIK dalam pertanian di desa dapat meningkatkan pendapatan penduduk desa dan meningkatkan pertumbuhan ekonomi (Patel and Sayyed, 2014). Selain itu, riset-riset tentang pengembangan website desa di Indonesia juga sudah dilakukan, seperti riset Mustangin et al. (2017), Ridha (2018) dan Desiani et al. (2020). Riset-riset tersebut membangun website desa untuk promosi wisata desa.

Namun masalahnya, transformasi model bisnis dari konvensional ke digital tentunya bukanlah hal yang mudah dilakukan. Banyak riset sudah dilakukan untuk meneliti faktor penghambat transformasi model bisnis, seperti riset yang dilakukan oleh Maria, Kristianto and Gundo (2012), Persulessy and Silaya (2017). Riset tersebut menemukan bahwa manusia dan dana investasi TIK adalah faktor penghambat utama implementasi TIK di UMKM. Faktorfaktor tersebut, juga diidentifikasi sebagai masalah yang muncul di perdesaan saat implementasi TIK dalam sistem pertanian (Bojkić et al., 2016), tak terkecuali di Dusun Srumbung Gunung, Desa Poncoruso. Hasil wawancara awal ditemukan sebagian besar petani dan pedagang di Dusun Srumbung Gunung memiliki keterbatasan pemahaman serta penguasaan TIK. Tak hanya itu, petani dan pedagang Dusun Srumbung Gunung juga memiliki keterbatasan waktu dan minat untuk belajar TIK. Petani dan pedagang di Dusun Srumbung Gunung juga, tidak memiliki dana yang cukup untuk melakukan investasi awal TIK, seperti komputer, aplikasi komputer, dan pelatihan TIK.

Menariknya, hasil riset Venkatesh and Swetha (2018) menemukan bahwa anak-anak muda desa di distrik Chikkaballapur, India ditemukan memiliki tingkat melek huruf yang tinggi. Oleh sebab itu, anak-anak muda desa dapat menjadi target potensial untuk di edukasi dalam rangka menggerakkan pemasaran digital di perdesaan. Anak-anak muda desa, sudah tidak asing menggunakan ponsel pintar dan telah mengakses berbagai media sosial, seperti facebook dan whatsapp. Anak muda di desa juga mengalokasikan uang untuk membeli kuota internet 
setiap bulannya, sehingga bukan hal mustahil jika desa dapat mentransformasi bisnisnya ke model pemasaran digital melalui anak-anak muda desa.

Berdasarkan riset Venkatesh and Swetha (2018) maka sebelum membangun website Pasar Dusun perlu dilakukan identifikasi terlebih dahulu apakah anak-anak muda Dusun Srumbung Gunung memiliki potensi untuk di edukasi. Hasil wawancara awal ditemukan bahwa anakanak muda Dusun Srumbung Gunung yang memiliki tingkat melek huruf dan teknologi yang baik akan dipilih untuk dilatih sebagai administrator website Pasar Dusun. Jadi, ada dua tujuan kegiatan pengabdian kepada masyarakat ini. Pertama, membangun website Pasar Dusun untuk berjualan produk dan potensi Dusun Srumbung Gunung dan sekitarnya dalam jangkauan yang lebih luas, sehingga diharapkan dapat meningkatkan pendapatan dan kesejahteraan masyarakat Dusun Srumbung Gunung pasca Covid-19. Kedua, melatih dan menyiapkan administrator website Pasar Dusun, yang akan berperan sebagai pengelola transaksi jual beli yang terjadi dalam website Pasar Dusun.

\section{METODE PENERAPAN}

Kegiatan pengabdian kepada masyarakat ini dilakukan di Dusun Srumbung Gunung, Desa Poncoruso, Kecamatan Bawen, Kabupaten Semarang. Dusun ini dipilih karena desa ini merupakan desa mitra pengabdian kepada masyarakat skim Program Pengembangan Desa Mitra (PPDM) Ristek Dikti tahun 2020. Kegiatan pengabdian kepada masyarakat dilakukan dengan pendekatan deskriptif baik secara kuantitatif maupun kualitatif. Ada dua metode penerapan kegiatan pengabdian kepada masyarakat. Pertama, pendampingan pembuatan website Pasar Dusun. Kegiatan ini, dilakukan dari tanggal 24 Juli-13 Agustus 2020. Pada tahap ini peserta kegiatan diminta untuk menyiapkan persyaratan administrasi untuk pembukaan website, mulai dari nama, logo, alamat, kontak, dan rekening bank khusus untuk transaksi di toko online. Peserta kegiatan juga di minta untuk mendata produk-produk yang akan dipasarkan di website, mulai dari pemilik, foto, deskripsi, serta berat dan dimensi produk (Maria, 2020). Kedua, pelatihan administrator website Pasar Dusun. Kegiatan ini dilakukan tanggal 13 Agustus 2020.

Keberhasilan kegiatan pengabdian kepada masyarakat ini dapat diukur menggunakan tiga indikator. Pertama, tersedianya website Pasar Dusun yang dapat diakses dan dapat melakukan transaksi jual beli secara online. Kedua, administrator website Pasar Dusun dapat melakukan pengelolaan toko online-nya mulai dari unggah foto produk, penjualan, pengiriman, sampai dana dilepas ke pemilik barang. Ini ditunjukkan dengan jumlah barang yang di unggah di website, jumlah transaksi dan testimoni dari pembeli. Ketiga, omset transaksi penjualan barang melalui website, sehingga berdampak pada peningkatan pendapatan pelaku bisnis di Dusun Srumbung Gunung dan sekitarnya.

\section{HASIL DAN KETERCAPAIAN SASARAN}

Peserta kegiatan pengabdian ini ada enam orang anak muda Dusun Srumbung Gunung. Keenam anak muda ini bukan hanya anggota dari organisasi KTMT tetapi juga merupakan pengurus dari organisasi masyarakat Dusun Srumbung Gunung yang dikenal dengan nama Creative Peace Srumbung Society (CPSS). CPSS adalah organisasi yang menginisiasi pembentukan Desa Wisata Kreatif Perdamaian (DWKP). Dalam kegiatan ini, CPSS akan menjadi pihak pengelola website Pasar Dusun. 


\section{Konsep Pemasaran Digital Dusun Srumbung Gunung}

Maria et al.

Pada sesi ini dilakukan pemaparan tentang definisi pemasaran digital dan siklus pemasaran digital kepada peserta kegiatan pengabdian kepada masyarakat. Pemasaran digital merupakan penggunaan teknologi digital untuk menciptakan hubungan komunikasi yang ditargetkan dan terukur yang dapat membantu dan mempertahankan pelanggan serta membangun jaringan kerjasama yang lebih baik dengan pelanggan, pemasok, investor terkait dengan merk, produk, dan kemajuan bisnis (Royle \& Laing, 2014). Pemasaran digital membuka kesempatan para pelaku bisnis untuk melakukan kolaborasi sehingga dapat memperoleh keuntungan bisnis dengan mempromosikan produk atau layanan (Purkayastha \& Sharma, 2016). Jadi, pemasaran digital adalah pemasaran produk atau layanan menggunakan saluran digital berbasis internetuntuk menjangkau konsumen lebih luas.

Data statistika yang ditabulasikan oleh katadata.co.id menunjukkan bahwa Indonesia termasuk dalam sepuluh negara dengan pengguna internet terbesar di dunia. Indonesia berada di peringkat kelima dengan 143,26 juta pengguna internet per Maret 2019. The Global Web Index juga mencatat bahwa Indonesia juga memiliki tingkat penggunaan e-commerce tertinggi di dunia. 96 persen pengguna internet telah mencari produk atau layanan yang akan dibeli secara online. Ini berarti pemasaran online memiliki prospek yang bagus untuk memasarkan produk dalam jangkauan yang lebih luas, karena ada perubahan model konsumsi masyarakat dari semula di toko fisik ke e-commerce.

Setelah penjelasan tentang konsep pemasaran digital, sesi dilanjutkan dengan penjelasan model pemasaran digital dan siklus binis pemasaran digital yang akan diterapkan di Dusun Srumbung Gunung. Mengingat ada keterbatasan keterampilan dan penguasaan TIK di kalangan pelaku bisnis Dusun Srumbung Gunung, maka pemasaran online di Dusun ini akan menggunakan konsep satu toko online berbasis website. Toko online ini akan dijalankan dengan model konsinyasi. Artinya petani, pedagang, dan/atau UMKM Dusun Srumbung Gunung dan sekitarnya dapat menitipkan produk-produknya untuk di jual di toko online, yaitu website Pasar Dusun. Para pemilik barang dagangan tidak perlu mengunggah produknya sendiri ke dalam toko online. Pemilik barang dan jasa cukup menitipkan barang dengan memberikan foto produk serta informasi produk terkait deskripsi produk serta harga ketika hendak berjualan di website Pasar Dusun. Selanjutnya, ada middleman, yaitu pengelola website bertugas untuk mengurus transaksi jual beli di website Pasar Dusun, mulai dari tugas mengunggah foto dan deskripsi produk, mendata produk dan pemasok barang, penjualan, pengiriman hingga uang dilepas kepada para pemasok barang. Middleman adalah orang yang terpilih untuk didampingi dan dilatih dalam kegiatan ini, yaitu enam anak muda yang merupakan anggota KTMT dan pengurus di CPSS.

\section{Pembukaan Website Pasar Dusun dan Pelatihan Administrator Website}

Pemasaran digital mensyaratkan pengguna, yaitu pemilik toko untuk memiliki aplikasi yang dapat digunakan untuk transaksi jual beli secara online. Dalam kegiatan pengabdian kepada masyarakat ini, pemasaran digital di Dusun Srumbung Gunung memanfaatkan marketplace yang sudah ada, yaitu Sakoo (Satu Toko Online). Sakoo dipilih menjadi platform pemasaran digital karena aplikasi ini sudah jadi, sehingga dapat segera diimplementasikan di Dusun Srumbung Gunung. Sakoo menyediakan fitur-fitur, berupa pengelolaan stok, transaksi, data pelanggan, dan katalog produk yang dibutuhkan oleh pelaku bisnis di Dusun Srumbung Gunung untuk transaksi perdagangannya. Pemasaran digital menggunakan aplikasi Sakoo membuat interaksi masyarakat dalam beraktivitas akan lebih diminimalisir, sehingga risiko 
kontak terhadap penyebaran Covid-19 juga dapat diminimalisir, tanpa mengurangi pemenuhan kebutuhan sandang dan pangan rumah tangga.

Toko online Dusun Srumbung Gunung akan diberi nama Pasar Dusun. Sebelum membuka website Pasar Dusun, tim pengabdian melakukan pendampingan untuk memberikan pemahaman pada CPSS terkait logo toko, sistem pembayaran, dan sistem pengiriman produk. Tiga hal ini memegang peranan penting untuk keberhasilan pemasaran digital. Logo toko memberi kesan pertama bahwa toko online dikelola secara profesional. Logo juga akan meningkatkan kepercayaan konsumen terhadap bisnis yang dijalankan. Logo juga berguna untuk membedakan antara toko yang satu dengan toko lain yang sejenis dan menjual produk yang sama. Logo memudahkan konsumen mengingat toko yang kunjungi, karena bagi sebagian besar konsumen akan lebih mudah mengingat logo dibandingkan mengingat nama. Adapun logo Pasar Dusun ditunjukkan pada Gambar 1.

Sistem pembayaran di aplikasi Sakoo menggunakan payment gateway, yaitu sistem transaksi online yang mengotorisasi proses pembayaran transaksi menggunakan transfer bank maupun pembayaran langsung lainnya. Oleh sebab itu, CPSS tidak perlu lagi menyediakan rekening dari berbagai bank untuk menjalankan transaksi jual beli di website Pasar Dusun nantinya. Payment gateway bisa menerima dana transfer dari berbagai rekening bank dan langsung menyalurkannya ke satu rekening milik toko online. Pemrosesan transaksi pembayaran pun mudah, cepat dan aman. CPSS hanya perlu menyediakan satu nomor rekening saja untuk menjalankan transaksi jual beli di website Pasar Dusun, yaitu rekening milik CPSS.

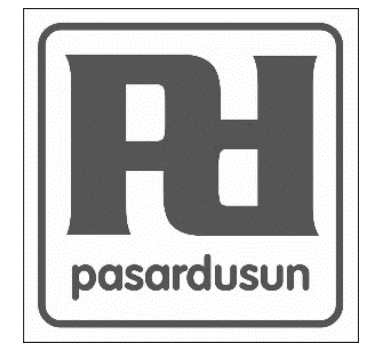

Gambar 1. Logo Toko OnlinePasar Dusun

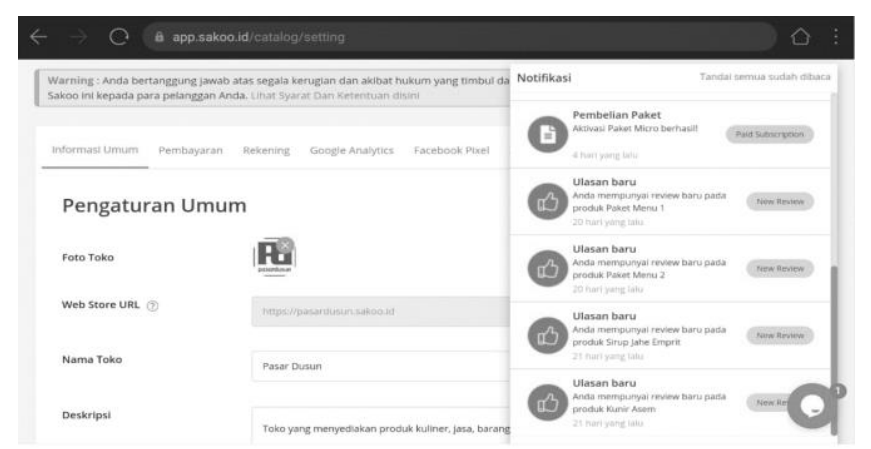

Gambar 2. Halaman Web sakoo.id untuk Pengaturan Pembukaan Pasar Dusun

Aplikasi Sakoo menyediakan fitur layanan pengiriman produk dari penjual ke pembeli yang terintegrasi, mulai dari penjemputan, pengepakan, dan pengantaran produk, hingga pencetakan label dan penginputan nomor resi pengiriman produk. Banyak pilihan Kerjasama pengiriman yang disediakan aplikasi tersebut, mulai dari ekspedisi nasional hingga mengakomodasi ekspedisi kurir pribadi. Pasar Dusun dapat menggunakan dua tipe ekspedisi tersebut. Dasar pemilihan jasa ekspedisi nasional adalah jarak agen kurir terdekat dengan lokasi toko. CPSS juga dapat menggunakan ekspedisi kurir pribadi untuk mengirimkan produk-produk kuliner tertentu. Kurir pribadi dapat ditangani pengelolaannya oleh CPSS dan penetapan tarif pengiriman juga dapat diatur dan ditetapkan sendiri oleh CPSS. Perhitungan ongkos kirim juga dilakukan secara otomatis, sehingga penting untuk mengatur lokasi toko, berat dan dimensi produk dengan benar, sehingga ongkos kirim menjadi tepat jika dihitung dalam sistem. 
Seperti halnya membuka sebuah gerai dalam sebuah mall, demikian juga membuka toko baru dalam sebuah marketplace, penjual juga harus memesan tempat untuk memasarkan produk yang akan dipasarkannya. Setelah persyaratan administrasi terkumpul, maka kegiatan pembukaan toko pun dilakukan. Dalam kegiatan ini diajarkan mulai dari cara membuka toko sampai siap beroperasi. Sebelum membuka toko online di aplikasi Sakoo, pengelola Pasar Dusun, yaitu CPSS harus membuka email khusus toko terlebih dulu, dengan alamat email pasardusunsrumbung@gmail.com. Email tersebut berfungsi sebagai tempat notifikasi dari toko online jika ada transaksi jual beli. Setelah itu, proses dilanjutkan dengan melakukan pembukaan toko online di website Sakoo.id melalui menu daftar disini dan memasukan email toko. Setelah itu, proses dilanjutkan ke menu Pengaturan Umum, seperti yang ditunjukkan pada Gambar 6. Pada menu tersebut, CPSS diminta untuk mengunggah logo toko, nama toko, dan deskripsi tentang toko. Alamat website toko, terisi langsung oleh sistem dengan alamat https://pasardusun.sakoo.id/. Halaman muka website toko ditunjukkan pada Gambar 3.
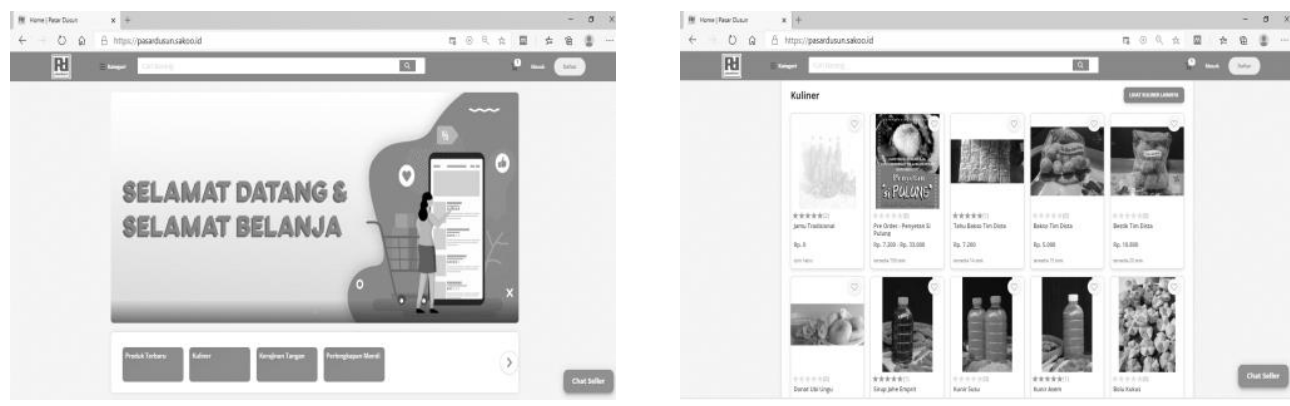

Gambar 3. Halaman Muka Website Pasar Dusun

Kegiatan dilanjutkan ke sesi pelatihan administrator website Pasar Dusun untuk mengisi toko dengan produk-produk yang akan dijual. Gambar 4 menunjukkan suasana pelatihan administrator website. Proses mengisi toko dengan barang dagangan dimulai dengan mengunggah foto/gambar produk, memberi nama produk, memasukkan harga jual, harga dari pemilik barang, deskripsi/spesifikasi produk, berat dan dimensi produk, ketersediaan produk, dan jumlah stok. Pada pelatihan ini berhasil dibuat etalase yang menampilkan produk yang dititipkan di website Pasar Dusun, seperti yang ditunjukkan pada Gambar 5.

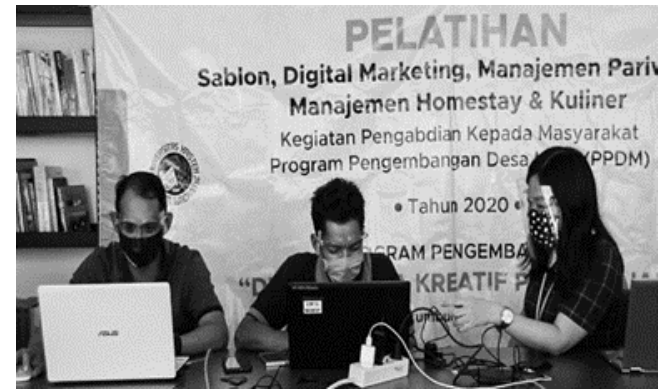

Gambar 4. Suasana Pelatihan Administrator Website Pasar Dusun

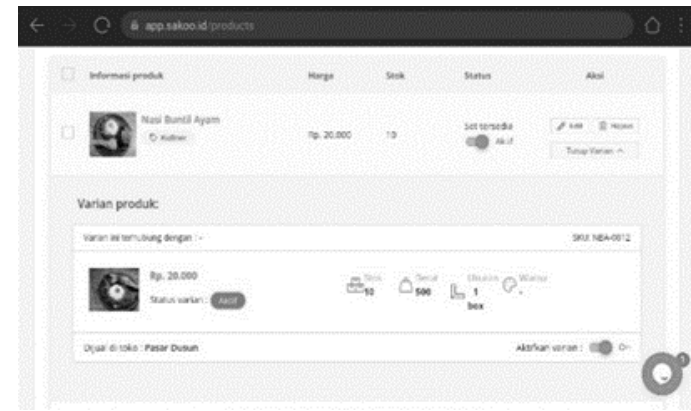

Gambar 5. Etalase Toko Pasardusun 
kuliner, kerajinan tangan, dan perlengkapan mandi dengan total 70 produk yang aktif dipasarkan di sana, 1 produk tidak aktif, dan 1 produk habis, seperti yang tersaji dalam Gambar 6. Sejak di buka, sudah ada 9 transaksi jual beli yang berhasil dilakukan di website Pasar Dusun. Gambar 7 menyajikan laporan akuntansi Pasar Dusun per tanggal 13 Agustus 2020 sampai dengan 19 September 2020. Dari laporan tersebut, diketahui ada 165 produk yang telah berhasil terjual melalui website toko tersebut. Adapun total penjualan kotor selama website Pasar Dusun beroperasi, yaitu sebesar Rp. 4.239.200 (empat juta dua ratus tiga puluh sembilan dua ratus rupiah). Angka ini tentunya memberi semangat bagi CPSS dan pelaku bisnis di Dusun Srumbung Gunung dan sekitarnya untuk berjualan di website Pasar Dusun.

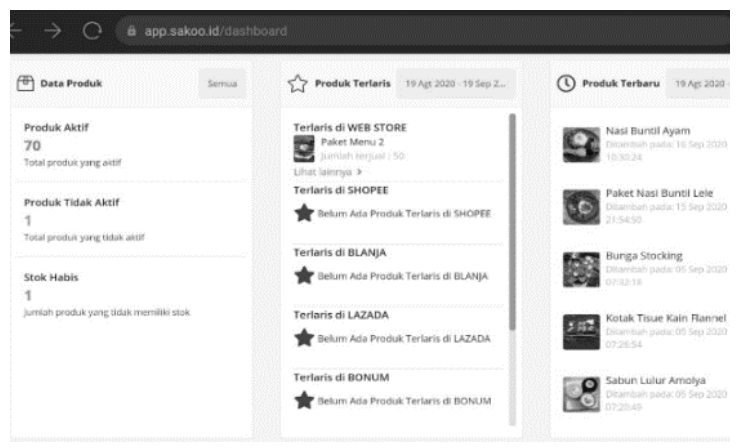

Gambar 6. Dashboard Produk

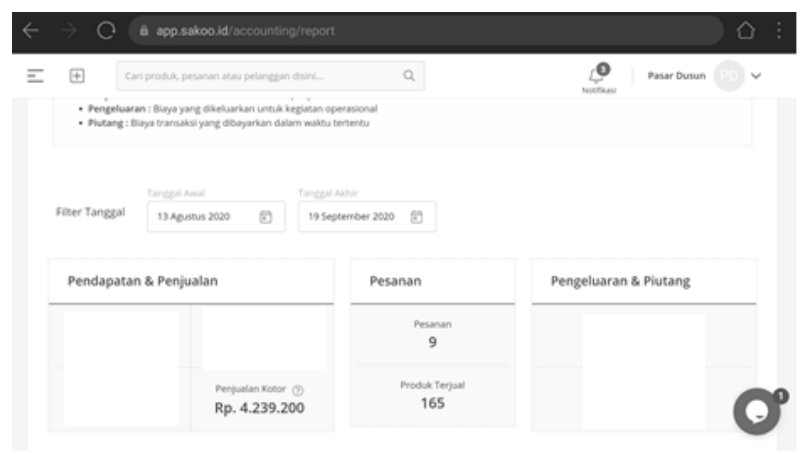

Gambar 7. Dasboard Laporan Akuntansi

\section{KESIMPULAN}

Hasil kegiatan pengabdian kepada masyarakat ini adalah tersedianya website Pasar Dusun untuk tempat jual beli produk dan potensi Dusun Srumbung Gunung dan sekitarnya secara online. Website mulai beroperasi sejak tanggal 13 Agustus 2020. Website dapat di akses pada https://pasardusun.sakoo.id/. Pasar Dusun memiliki banyak pemasok barang. Barang yang dipasarkan di website Pasar Dusun adalah barang konsinyasi/titipan. Pemilik barang hanya perlu memberikan foto dan deskripsi produk yang lengkap kepada pengelola website. Pengelola website adalah lima anak muda yang tergabung dalam Karang Taruna dan Creative Peace Srumbung Society (CPSS). Pengelola website berperan mengelola transaksi jual beli yang ada di website Pasar Dusun mulai dari unggah foto produk, transaksi jual beli, pengiriman barang, sampai dengan pembayaran ke pemilik barang. Sejak dibuka sampai dengan 19 September 2020, Pasar Dusun berhasil menjual 165 produk titipan para pedagang Dusun Srumbung Gunung dan berhasil membukukan penjualan kotor sebesar Rp. 4.239.200. Angka tersebut memberi semangat baik pada CPSS dan pelaku bisnis Dusun Srumbung Gunung yang sudah berjualan melalui website Pasar Dusun untuk meningkatkan produksi dan kualitas usahanya.

Namun, masih ada beberapa hambatan terkait pemasaran digital di Dusun Srumbung Gunung. Pertama, pemasok barang di Pasar Dusun pun masih sedikit jumlahnya. Oleh sebab itu, dukungan dari pemerintah desa dan organisasi kemasyarakatan, seperti KTMT dan CPSS masih diperlukan untuk memberikan keyakinan bahwa berjualan secara online melalui website Pasar Dusun aman dan dapat meningkatkan penghasilan masyarakat pasca Covid-19. Kedua, CPSS masih mengalami kesulitan dalam mendata dan mengkode produk di website Pasar Dusun. Oleh sebab itu, kegiatan pendampingan pada pengelola website Pasar Dusun masih diperlukan agar pengelola bisa melakukan pendataan produk dan pengelolaan stok produk di website Pasar Dusun dengan baik. 


\section{UCAPAN TERIMA KASIH}

Terimakasih kepada RISTEK DIKTI atas bantuan pendanaan untuk menjalankan Kegiatan Pengabdian kepada Masyarakat dalam Program Pengembangan Desa Mitra tahun 2020.

\section{Daftar Pustaka}

1. Awiagah, R., Kang, J., \& Lim, J. I. (2016). Factors affecting e-commerce adoption among SMEs in Ghana. Information Development, 32(4), 815-836. https://doi.org/https://doi.org/10.1177/0266666915571427

2. Badan Pusat Statistik. (2020). Berita Resmi Statistik: Pertumbuhan Ekonomi Indonesia Triwulan II-2020. In Badan Pusat Statistik.

3. Bojkić, V., Vrbančić, M., Žibrin, D., \& Čut, M. (2016). Digital Marketing in Agricultural Sector. Proceedings of the ENTRENOVA - ENTerprise REsearch InNOVAtion Conference, 136-141.

4. Desiani, A., Yahdin, S., Irmeilyana, I., \& Rodiah, D. (2020). Inovasi digitalisasi promosi potensi dan produk usaha masyarakat desa berbasis website di Desa Bangsal Kecamatan Pampangan. Riau Journal of Empowerment, 3(1), 49-59. https://doi.org/10.31258/raje.3.1.49-59

5. Fernandez, A. A., \& Shaw, G. P. (2020). Academic Leadership in a Time of Crisis: The Coronavirus and COVID-19. Journal of Leadership Studies. https://doi.org/10.1002/jls.21684

6. Firman. (2020). Ini Strategi Pemulihan Ekonomi Desa Pasca COVID-19. Kementerian Desa Pembangunan Daerah Tertinggal Dan Transmigrasi Republik Indonesia. https://www.kemendesa.go.id/berita/view/detil/3281/ini-strategi-pemulihan-ekonomi-desapasca-covid-19

7. Hoffman, D., Novak, T., \& Chatterjee, P. (1995). Commercial Scenarios for the Web: Opportunities and Challenges. Journal of Computer-Mediated Communication, 1(3).

8. Kurnia, S., Choudrie, J., Mahbubur, R., \& Alzougool, B. (2015). E-commerce Technology Adoption: A Malaysian Grocery SME Retail Sector Study. Journal of Business Research, 68(9), 1906-1918. https://doi.org/https://doi.org/10.1016/j.jbusres.2014.12.010

9. Maria, E. (2020, September). UKSW Salatiga Luncurkan Situs Pasar Dusun Bantu Warga Desa Pasarkan Produk. Tribun Jateng.Com. https://jateng.tribunnews.com/2020/09/09/uksw-salatigaluncurkan-situs-pasar-dusun-bantu-warga-desa-pasarkanproduk?fbclid=IwAR39yFFRatHh18ueHt6VLBSAOfgZy83HVItbQkde77Z9mP9g8gl7KSaPAU

10. Maria, E., Kristianto, B., \& Gundo, J. A. (2012). Adopsi Teknologi Informasi dalam Rangka Peningkatan Daya Saing Usaha Kecil Menengah di Kota Semarang. Jurnal Akuntansi Dan Keuangan Daerah, 1(2).

11. Maya, S. (2016). Peran e-Commerce untuk Meningkatkan Daya Saing Usaha Kecil dan Menengah (UKM). Jurnal Desain Komunikasi, 25(1), 22-31.

12. Mustangin, Kusniawati, D., Islami, N., Setyaningrum, B., \& Prasetyawati, E. (2017). Pemberdayaan Masyarakat Berbasis Potensi Lokal Melalui Program Desa Wisata di Desa Bumiaji. Sosioglobal: Jurnal Pemikiran Dan Penelitian Sosiologi, 2(1), 59-72. https://doi.org/10.24198/jsg.v2i1.15282 10

13. Patel, S., \& Sayyed, I. (2014). Impact of Information Technology in Agriculture Sector International Journal of Food, Agriculture and Veterinary Sciences, 4(2), 17-22. http://www.cibtech.org/jfav.htm

14. Pembatasan Sosial Berskala Besar Dalam Rangka Percepatan Penanganan Corona Virus Disease 2019 (COVID-19), (2020). https://jdih.setkab.go.id/PUUdoc/176085/PP_Nomor_21_Tahun_2020.pdf

15. Persulessy, G., \& Silaya, M. (2017). Tingkat Kesiapan Adopsi Teknologi Informasi Pada Usaha Kecil dan Menengah Kerang dan Mutiara di Kota Ambon. Seminar Nasional Inovasi Teknologi Informasi. 
16. Purkayastha, A., \& Sharma, S. (2016). Gaining Competitive Advantage Through the Right Business Model: Analysis Based on Case Studies. Journal of Strategy and Management, 9(2), 138-155. https://doi.org/10.1108/JSMA-07-2014-0060

17. Ridha, M. R. (2018). Website Desa Sebagai Sarana Promosi Potensi Desa Lintas Utara Kab. Indragiri Hilir. SISTEMASI: Jurnal Sistem Informasi, 7(3), 204-211. https://doi.org/10.32520/stmsi.v7i3.394

18. Royle, J., \& Laing, A. (2014). The Digital Marketing Skills Gap: Developing a Digital Marketer Model for the Communication Industries. International Journal of Information Management, 34(2), 65-73. https://doi.org/10.1016/j.ijinfomgt.201 3.11.008

19. Shen, S., Basis, A., \& Howard, A. (2010). Structure of a digital agriculture system and agricultural risks due to climate changes. International Conference on Agricultural Risk and Food Security, 42-51.

20. Utomo, W. H., Retnowati, \& Maria, E. (2015). Mobile Commerce Modeling and Building for Small and Medium Enterprises. International Review on Computers and Software (I.RE.CO.S.), 10(11), 1096-1102.

21. Utomo, W. H., Retnowati, \& Maria, E. (2014). Dampak Teknologi Mobile pada Model Bisnis Umkm Batik Plumpungan, Salatiga. Seminar Nasional Inovasi Teknologi Informasi, 62-68.

22. Venkatesh, B., \& Swetha. (2018). A Study on Avenues for Digital Marketing In Rural Areas With Respect To Chickballapura District. International Journal of Advance in Management, Technology and Engineering Sciences, 8(1), 1-13. 